University of Nebraska - Lincoln

DigitalCommons@University of Nebraska - Lincoln

Occurrence of Pesticides in Ground Water of the North Platte Natural Resources District, Nebraska, 2002

\author{
G. V. Steele \\ U.S. Geological Survey \\ J. C. Cannia \\ North Platte Natural Resources District
}

Follow this and additional works at: https://digitalcommons.unl.edu/usgspubs

Steele, G. V. and Cannia, J. C., "Occurrence of Pesticides in Ground Water of the North Platte Natural Resources District, Nebraska, 2002" (2003). Publications of the US Geological Survey. 107.

https://digitalcommons.unl.edu/usgspubs/107

This Article is brought to you for free and open access by the US Geological Survey at DigitalCommons@University of Nebraska - Lincoln. It has been accepted for inclusion in Publications of the US Geological Survey by an authorized administrator of DigitalCommons@University of Nebraska - Lincoln. 


\section{Occurrence of Pesticides in Ground Water of the North Platte Natural Resources District, Nebraska, 2002}

\section{-G.V. Steele ${ }^{1}$ and J.C. Cannia ${ }^{2}$}

Ground water is the source of drinking water for all residents of the North Platte Natural Resources District (NPNRD). Most of the drinking water in the NPNRD comes from unconfined aquifers that are part of the regional High Plains aquifer. The water tables of these local aquifers lie close to the land surface. As a result, the aquifers can be affected by infiltration of irrigation waters that are prone to contain contaminants. Once in the aquifer, contaminants can adversely affect drinking-water supplies.

${ }^{1}$ U.S. Geological Survey, Lincoln, Nebraska.

${ }^{2}$ North Platte Natural Resources District, Gering, Nebraska.
In 2002, the U.S. Geological Survey (USGS) and the NPNRD began a cooperative study to determine whether or not 112 pesticides and selected degradation products occur in ground water of the NPNRD. Forty-one monitoring wells at 23 sites (fig. 1) throughout the NPNRD were selected for sampling to determine the areal occurrence of pesticides. This fact sheet summarizes the results of the 2002 sampling.

\section{Introduction}

The study area encompasses all of the NPNRD (fig. 1). The dominant land use in the North Platte River and Pumpkin Creek Valleys of the NPNRD is agricultural row crop production, predominantly corn. Other crops include sugar beets, alfalfa, soybeans, and dry beans. Upland areas primarily are used as pastureland, but have some row crops. The primary aquifer in the NPNRD contains Quaternary-age sand and gravel deposits interspersed with layers of clay. Most of the aquifer lies in the alluvial valleys of the North Platte River and Pumpkin Creek (fig. 1).

Previous studies, including Exner (1990), Verstraeten and others (1995), and Steele and others (1998), have

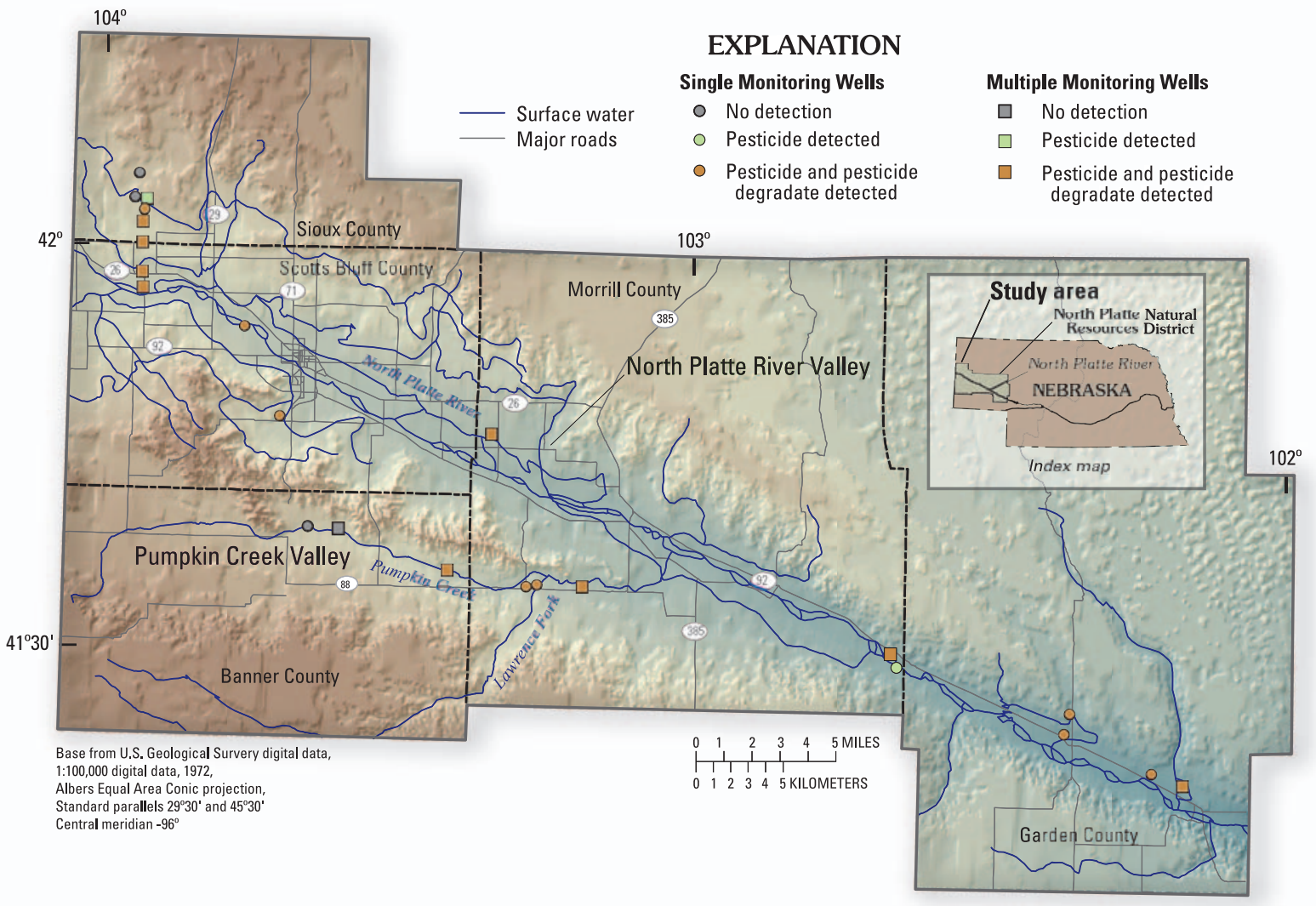

Figure 1. Location of the study area and wells with detections of pesticides and pesticide degradate compounds. 
reported that pesticide concentrations in the ground water of the NPNRD typically are low and occurrence is sporadic. However, the shallowest ground water would be the affected by a downward flux of agricultural chemicals from the land surface. For the study described in this report most of the emphasis was placed on determining pesticide concentrations in shallow ground water by sampling 41 wells during June 2002 . Twenty-eight shallow monitoring wells (less than 100 feet deep) and 13 deep monitoring wells (greater than 100 feet deep) were sampled at sites with single and multiple monitoring wells (fig. 1).

Ground-water samples were analyzed for 112 pesticide compounds, including 90 parent compounds (original compounds intended for pest control use) and 22 degradation products (compounds derived from biochemical breakdown of parent compounds). Pesticides include compounds most commonly used to control weeds (herbicides) and insects (insecticides). For this report, measurable amounts of pesticides, herein referred to as detected, describe samples where the concentration was greater than or equal to a laboratory reporting limit of 0.005 micrograms per liter (or parts per billion). Below this threshold, the quantification of the concentration and confidence in the presence of the pesticide or degradation products are less reliable. In June 2002, ground-water samples were collected for determination of field measurements (specific conductance, $\mathrm{pH}$, water temperature, and dissolved-oxygen concentration), and analysis for concentrations of major ions (including calcium, magnesium, potassium, chloride, and sulfate), nutrients (nitrate as nitrogen $(\mathrm{N})$, and phosphate), and pesticides. Collec- tion, preparation, and shipment of all ground-water samples were completed using standard USGS protocols (U.S. Geological Survey, 1997-present). All samples were analyzed at the USGS National Water Quality Laboratory in Denver, Colorado. Methods for analytical procedures used by the NWQL can be found on the World Wide Web at URL http://nwql.usgs.gov/Public/ref_list.html (accessed Dec. 4, 2003). These analytical data are stored in the USGS National Water Inventory System and are accessible at http://waterdata.usgs.gov/nwis. Seven quality-control samples (three blanks and two replicates) were sequentially collected with the environmental samples. Results from analysis of the quality-control samples indicate good reproducibility of the laboratory techniques, and that no contamination was introduced during field activities.

Table 1. Pesticide detections in ground-water samples, North Platte Natural Resources District, Nebraska, 2002

[All concentrations in micrograms per liter; MRL, minimum reporting limit; italicized text indicates pesticide degradation products; ESA, ethane sulfonic acid; OXA, oxanilic acid; --, none or not applicable]

\begin{tabular}{|c|c|c|c|c|c|c|}
\hline Pesticide & $\begin{array}{c}\text { Number } \\
\text { of } \\
\text { detections }\end{array}$ & $\begin{array}{l}\text { Percentage } \\
\text { of sites with } \\
\text { detections }\end{array}$ & $\begin{array}{c}\text { Median } \\
\text { concentration } \\
\text { above MRL }\end{array}$ & $\begin{array}{c}\text { Maximum } \\
\text { concentration }\end{array}$ & $\begin{array}{c}\text { Maximum } \\
\text { contaminant } \\
\text { level }\end{array}$ & CASRN\#1 \\
\hline \multicolumn{7}{|c|}{ Herbicide } \\
\hline Deethylatrazine & 28 & 68 & 0.02 & 0.91 & -- & -- \\
\hline Atrazine & 21 & 51 & .009 & .20 & 3.0 & -- \\
\hline Deethyldeisopropylatrazine & 21 & 51 & .02 & .89 & -- & -- \\
\hline Alachlor ESA & 20 & 49 & .10 & 3.0 & -- & -- \\
\hline Metolachlor ESA & 11 & 27 & .10 & 1.2 & -- & -- \\
\hline Prometon & 10 & 24 & .01 & .07 & -- & $1610-18-0$ \\
\hline Deisopropylatrazine & 9 & 22 & .01 & .10 & -- & -- \\
\hline 2-Hydroxyatrazine & 8 & 20 & .012 & .06 & -- & -- \\
\hline Simazine & 7 & 17 & .01 & .07 & 4.0 & -- \\
\hline Metolachlor $O X A$ & 5 & 12 & .10 & .20 & -- & -- \\
\hline Metolachlor & 3 & 7 & .009 & .011 & -- & $51218-45-2$ \\
\hline Acetochlor ESA & 2 & 5 & -- & .20 & -- & -- \\
\hline Bromacil & 1 & 2 & -- & .01 & -- & -- \\
\hline Diuron & 1 & 2 & -- & .02 & -- & $330-54-1$ \\
\hline Imazethapyr & 1 & 2 & -- & .05 & - & -- \\
\hline Nicosulfuron & 1 & 2 & -- & .01 & -- & -- \\
\hline Tebuthiuron & 1 & 2 & -- & .03 & -- & -- \\
\hline \multicolumn{7}{|c|}{ Insecticide } \\
\hline Picloram & 1 & 2 & -- & .67 & 500 & -- \\
\hline
\end{tabular}

${ }^{1}$ Chemical Abstract Service Registration Number (CASRN\#) for unregulated drinking water contaminants regulatory compliance documents (U.S. Environmental Protection Agency, 2001, http://www.epa.gov/OGWDW/dw_unregcontaminants.html\#1, accessed June 10, 2003). 


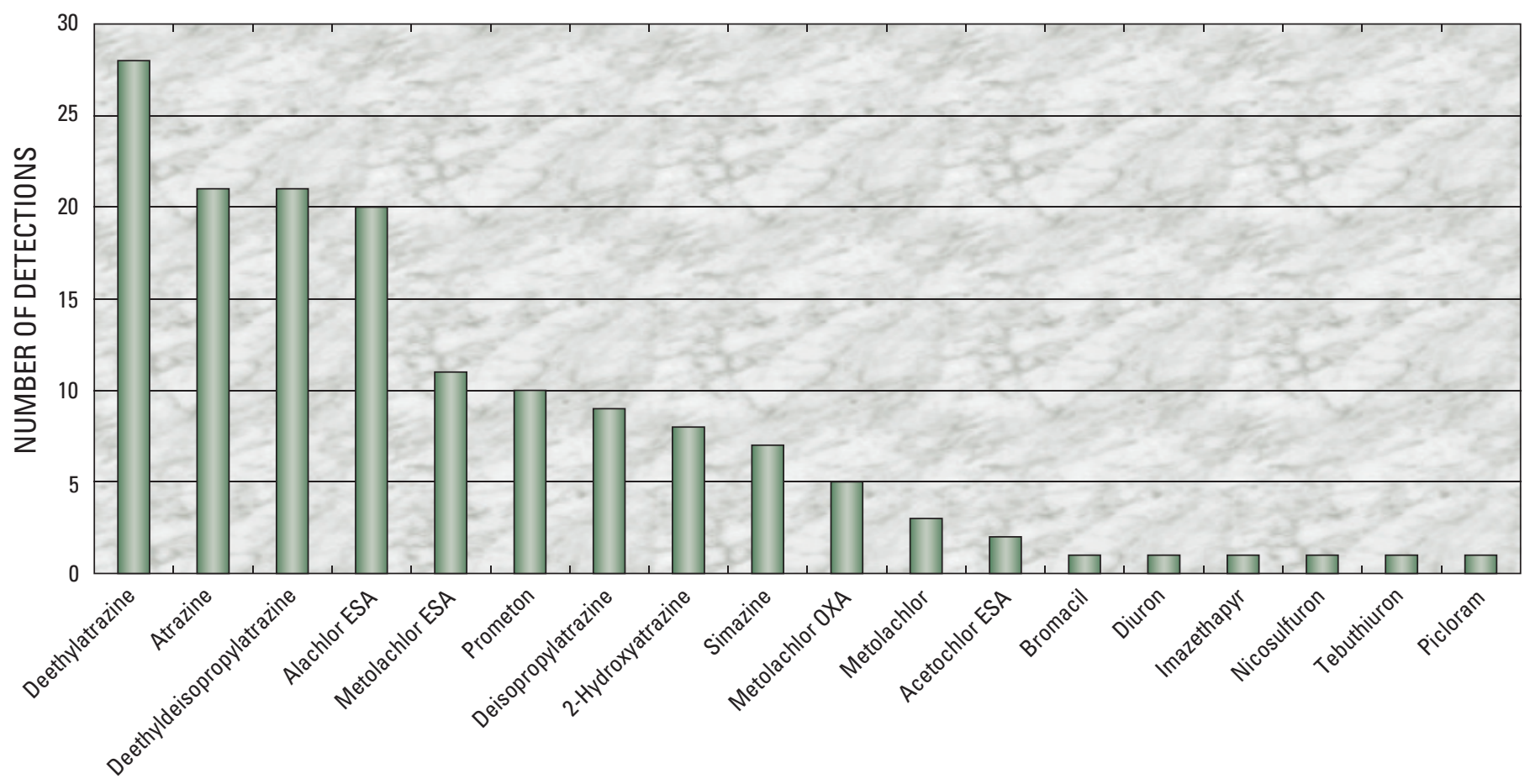

Figure 2. Frequency of pesticide detections in ground-water samples, North Platte Natural Resources District, 2002.

\section{Pesticides}

Nine herbicides, eight herbicide degradation products, and one insecticide were detected in water samples from the NPNRD sites (fig. 2, table 1). Pesticide compounds (includes parent and degradation products) were detected in 78 percent of water samples (32 of the 41). Pesticide degradation products were prevalent, accounting for 7 of the 10 most frequently detected compounds (table 1). None of the pesticides detected in ground-water samples exceeded the U.S. Environmental Protection Agency's (EPA) Maximum Contaminant Level (MCL) (U.S. Environmental Protection Agency, 2001) for pesticides in drinking water (table 1). The herbicide atrazine and its degradation products were the most frequently detected compounds consistent with the extensive use of atrazine in the NPNRD for decades. Atrazine and/or four atrazine degradation products were detected in 68 percent of the samples collected.

Of the 32 monitoring wells whose water samples contained pesticide compounds, 29 contained more than one pesticide. Two to eleven different pesticides were detected in each of these 29 wells. Pesticide compounds were detected in 86 percent ( 24 of 28 ) of the samples from wells less than 100 feet
Table 2. Minimum and maximum concentrations of pesticides by depth of well and number of detections in ground-water samples, North Platte Natural Resources District, Nebraska, 2002

[All results in micrograms per liter; italicized text indicates pesticide degradation product; number, number of monitoring wells with detections; ESA, ethane sulfonic acid; OXA, oxanilic acid; --, not detected or maximum concentration equals minimum concentration]

\begin{tabular}{|c|c|c|c|c|c|c|}
\hline \multirow{2}{*}{ Pesticide } & \multicolumn{3}{|c|}{$\begin{array}{c}\text { Monitoring wells shallower } \\
\text { than } 100 \text { feet }\end{array}$} & \multicolumn{3}{|c|}{$\begin{array}{c}\text { Monitoring wells deeper } \\
\text { than } 100 \text { feet }\end{array}$} \\
\hline & Number & Minimum & Maximum & Number & Minimum & Maximum \\
\hline Deethylatrazine & 20 & 0.005 & 0.417 & 8 & 0.01 & 0.91 \\
\hline Atrazine & 15 & .005 & .177 & 6 & .01 & .20 \\
\hline $\begin{array}{l}\text { Deethyldeisopro- } \\
\text { pylatrazine }\end{array}$ & 15 & .01 & .14 & 6 & .01 & .89 \\
\hline Alachlor ESA & 15 & .1 & 1.3 & 5 & .1 & .6 \\
\hline Metolachlor ESA & 9 & .1 & 1.2 & 2 & .1 & .3 \\
\hline Prometon & 9 & .01 & .07 & 1 & .01 & -- \\
\hline $\begin{array}{l}\text { Deisopropylatra- } \\
\text { zine }\end{array}$ & 6 & .01 & .02 & 3 & .01 & .1 \\
\hline 2-Hydroxyatrazine & 6 & .005 & .055 & 2 & .008 & .031 \\
\hline Simazine & 4 & .007 & .069 & 3 & .006 & .01 \\
\hline Metolachlor $O X A$ & 5 & .1 & .2 & -- & -- & -- \\
\hline Metolachlor & 3 & .008 & .011 & -- & -- & -- \\
\hline Acetochlor ESA & 1 & .1 & -- & 1 & .2 & -- \\
\hline Bromacil & 1 & .01 & -- & -- & -- & -- \\
\hline Diuron & 1 & .02 & -- & -- & -- & -- \\
\hline Imazethapyr & 1 & .05 & -- & -- & -- & -- \\
\hline Nicosulfuron & 1 & .01 & -- & -- & -- & -- \\
\hline Tebuthiuron & 1 & .03 & -- & -- & -- & -- \\
\hline Picloram & 1 & .67 & -- & -- & -- & -- \\
\hline
\end{tabular}




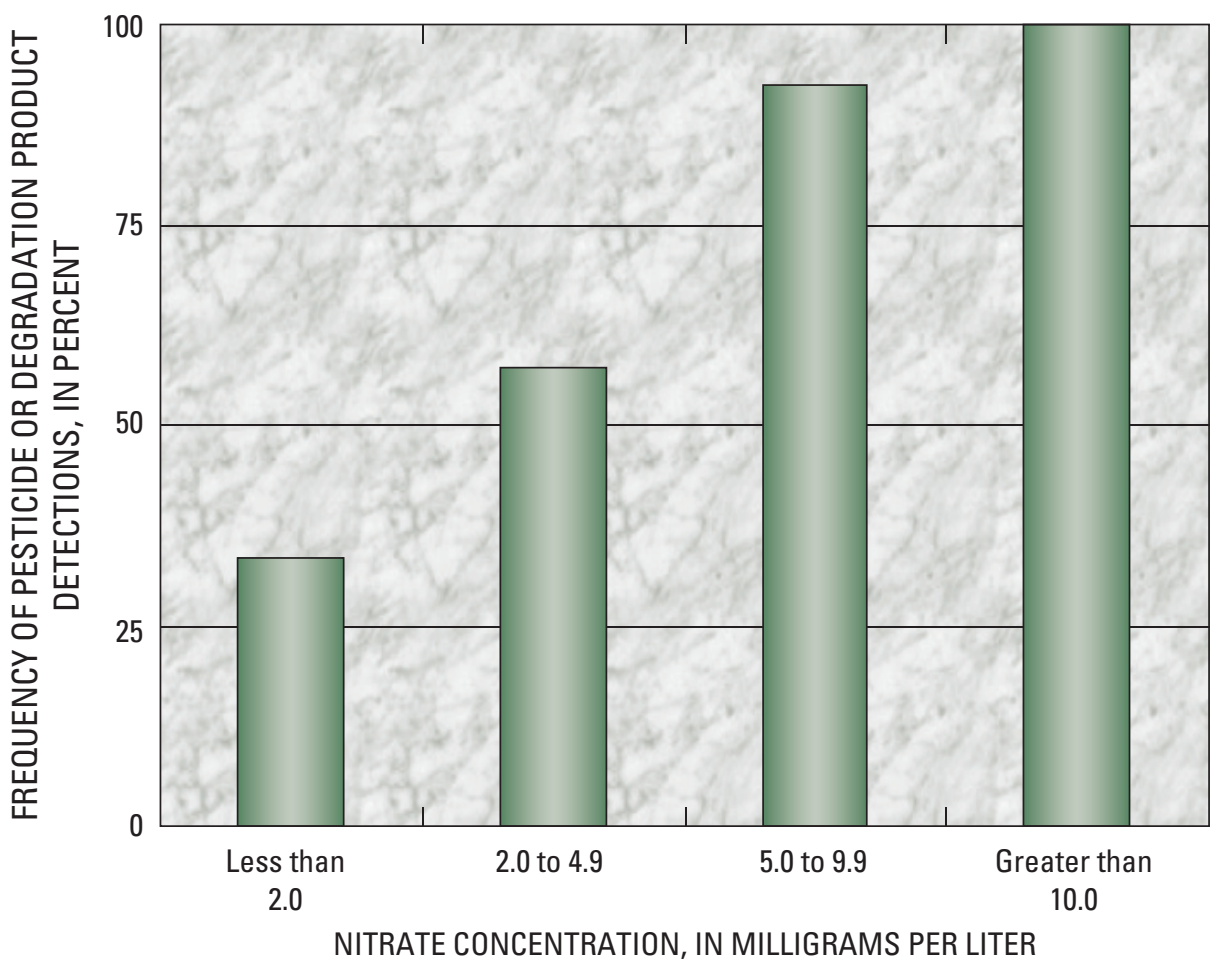

Figure 3. Pesticide detections as a function of nitrate concentrations in water samples, North Platte Natural Resources District, 2002.

deep, with 18 compounds detected. In comparison, pesticide compounds were detected in 62 percent ( 8 of 13) of the samples from wells deeper than 100 feet, with 10 compounds detected (table 2). Although pesticide compounds were detected less frequently at greater depths, the results indicate that pesticide compounds are being transported to deep ground water of the NPNRD in places.

Concentrations of nitrate as $\mathrm{N}$ in ground-water samples ranged from 0.31 milligrams per liter $(\mathrm{mg} / \mathrm{L}$, or parts per million) to $35 \mathrm{mg} / \mathrm{L}$, with a median concentration of $6.1 \mathrm{mg} / \mathrm{L}$. Eleven water samples contained concentrations higher than the EPA MCL of $10 \mathrm{mg} / \mathrm{L}$ of nitrate as nitrogen in drinking water (U.S.

Environmental Protection Agency, 2002). Figure 3 shows that pesticide compounds were detected more frequently as nitrate as $\mathrm{N}$ concentrations increased.

\section{Implications}

The results of the study indicate that pesticides were frequently detected in ground-water samples of the NPNRD. Nine herbicides, eight herbicide degradation products, and one insecticide of the 112 selected pesticides and degradation products analyzed for were detected in at

\section{References}

Exner, M.E., 1990, An investigation to determine the source of elevated nitrate concentrations in the ground water of the North Platte Valley west of Oshkosh, Nebraska: Report for the North Platte Natural Resources District, February 26, 1990, 23 p.

Steele, G.V., Cannia, J.C., and Stanton, J.S., 1998, Geohydrology and water quality of the North Platte River alluvial aquifer, Garden County, western, Nebraska, 1993-94: U.S. Geological Survey Water-Resources Investigations Report 98-4033, 75 p.

U.S. Environmental Protection Agency, 2002, Current drinking water standards-National Primary and Secondary Drinking Water Regulations: U.S. Environmental Protection Agency, Office of Ground Water and Drinking Water, accessed on March 22, 2003 at URL http://www.epa.gov/safewater/ mcl.html.

U.S. Geological Survey, 1997 to present, National field manual for the collection of water-quality data: U.S. Geological Survey Techniques of Water-Resources Investigations, book 9, chaps. A1-A9, $2 \mathrm{v}$., variously paged. [Also available online at http://pubs.water.usgs.gov/ twri9A. Chapters originally were published from 1997-1999; updates and revisions are ongoing and are summarized at: http://water.usgs.gov/ owq/FieldManual/mastererrata.html]

Verstraeten, I.M., Sibray, S.S., Cannia, J.C., and Tanner, D.Q., 1995, Reconnaissance of ground-water quality in the North Platte Natural Resources District, western Nebraska, JuneJuly 1991: U.S. Geological Survey Water-Resources Investigations Report 94-4057, 114 p.

dates were prevalent in ground water of the NPNRD, being 7 of the 10 most frequently detected compounds.

This study shows that pesticides compounds are present in many parts of the NPNRD, but they do not occur everywhere. Pesticide compounds are typically present in shallow (less than 100 feet deep) ground water areally across the NPNRD and are being transported to the deep parts (greater than 100 feet deep) of the aquifer in places.
For more information, contact: District Chief

U.S. Geological Survey

Federal Building, Room 406 100 Centennial Mall North Lincoln, NE 68508

Phone: 402-437-5082 e-mail: dc_ne@usgs.gov

Web site: http://ne.water.usgs.gov 